\title{
ASAH2C Gene
}

National Cancer Institute

\section{Source}

National Cancer Institute. ASAH2C Gene. NCI Thesaurus. Code C103908.

This gene may be involved in ceramide metabolism. 